\section{Phenology of an agarophyte Gracilaria birdiae Plastino and E.C. Oliveira (Gracilariales, Rhodophyta) in Northeastern Brazil}

\author{
Marcella A. A. Carneiro, ${ }^{1}$ Eliane Marinho-Soriano, ${ }^{2}$ Estela M. \\ Plastino $^{*}, 1$
}

${ }^{I}$ Departamento de Botânica, Instituto de Biociências, Universidade de São Paulo, Brazil,

${ }^{2}$ Departamento de Oceanografia e Limnologia, Instituto de Biociências, Universidade Federal do Rio Grande do Norte, Brazil.

\begin{abstract}
The reproductive phenology and thallus length of Gracilaria birdiae were studied over a period of 12 months in a natural bed in Northeastern Brazil. Fertile specimens of $G$. birdiae were observed during the entire study period. Tetrasporophytes were the most common with an annual mean of $80.1 \pm 5.6 \%$, followed by cystocarpic plants $(9.3 \pm 3.4 \%)$, male gametophytes $(8.3 \pm 3.6 \%)$ and infertile plants $(2.2 \pm 3.4 \%)$. Only male gametophytes and infertile plants showed a variation in occurrence frequency during the year $(p<0.05)$. With respect to thallus length, a distinct seasonal variation was observed for all reproductive stages $(p<0.05)$, with the highest values recorded during the rainy season (March to August) and the lowest in the dry season (September to February). The results demonstrate that the size of individuals in this population is significantly affected by the periodic changes in the environment caused by rainfall regimes and hydrodynamism.
\end{abstract}

Revista Brasileira de Farmacognosia Brazilian Journal of Pharmacognosy 21(2): 317-322, Mar./Apr. 2011

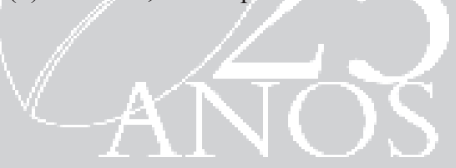

Article

Received 3 Jan 2011

Accepted 25 Jan 2011 Available online 22 Apr 2011

Keywords:

Gracilaria

reproductive phenology

algae

ISSN 0102-695X

doi: 10.1590/S0102-695X2011005000067

\section{Introduction}

The genus Gracilaria (Gracilariales, Rhodophyta) is widely distributed in tropical and temperate regions worldwide and is represented by more than 110 species (Critchley, 1993; Oliveira \& Plastino, 1994). This genus has significant economic importance in several countries due to its agar content and rapid growth (Armisen, 1995), currently accounting for around $65 \%$ of world agar production (McHugh, 2002). Gracilaria has a "Polysiphonia-type" life history, with morphological similarities between gametophytic (n) and tetrasporophytic (2n) phases. However, the occurrence of different reproductive structures in a same thallus can be observed, which may be related to mechanical (in situ tetraspore germination), genetic or cytological failures (Oliveira \& Plastino, 1994; Kain (Jones) \& Destombe, 1995).

Studies conducted on natural populations of Gracilaria demonstrate a greater predominance of tetrasporophytic forms, in addition to indicating a lower amount of male than female gametophytes (Marinho-Soriano et al., 1998; Orduña-Rojas \& Robledo, 2002; Polifrone et al., 2006). This variation is related mainly to different survival and fertility rates between haploid and diploid individuals (Richerd et al., 1993). The occurrence frequency of Gracilaria reproductive stages has been determined for several species in geographically distinct regions. In the tropics, fertile individuals are present in populations throughout the year, while in temperate regions fertility peaks are restricted to one or two periods, generally when temperatures and irradiances are highest (Kain (Jones) \& Destombe, 1995; Espinoza-Avalos, 2005). Thus, some species of Gracilaria exhibit reproductive strategies that allow synchrony between fertile periods and favorable environmental conditions for their perennity (Marinho-Soriano et al., 1998). In Brazil, phenological studies on the genus Gracilaria are relatively scarce (Pinheiro-Joventino \& Bezerra, 1980; Plastino, 1985; Silva et al., 1987; Araújo, 2005).

Gracilaria birdiae Plastino and E.C. Oliveira, one of the main sources of agar in the country, is found from the coast of Ceará State $\left(3^{\circ} \mathrm{S}\right)$ to Espirito Santo State $\left(20^{\circ} \mathrm{S}\right)$, Brazil, in relatively abundant beds of perennial seaweeds (Plastino \& Oliveira, 2002). This species has recently been the focus of several laboratory studies (Plastino, 2004) and its life history has been completed in a laboratory culture (Costa \& Plastino, 2001). Strain selection and the physiological demands of the strains were performed with the aim of improving cultivation techniques in the sea (Costa \& Plastino, 2011; Ursi \& Plastino, 2001; Ursi et al., 2003; Plastino et al., 2004; Ursi et al., 2008). Studies related to the cultivation of this 
species have been conducted in different environments such as shrimp ponds (Marinho-Soriano et al., 2009; Oliveira, 2007), estuaries (Marinho-Soriano et al., 2006) and the sea (Bezerra \& Marinho-Soriano, 2010), showing promising growth rates.

In the state of Rio Grande do Norte, extractivist harvesting of $G$. birdiae is performed by coastal communities, playing an important role in the local economy. Harvest occurs throughout the year during low tides and the short time interval between one harvest and the next is not sufficient to permit the complete recovery of seaweed beds. Thus, this activity is mainly responsible for the gradual decrease of seaweed stocks in the region, making the situation of these natural resources in the country increasingly worrisome. The objective of the present study was to estimate the reproduction of a natural population of $G$. birdiae based on the occurrence of different reproductive stages over a period of one year, as well as variations in thallus length as a function of seasonal environmental changes.

\section{Materials and Methods}

\section{Site location and collection}

A perennial infralittoral population of Gracilaria birdiae was studied at Rio do Fogo Beach (5¹5'41"S-35²3'11"W), Rio Grande do Norte State, located on the Northeast coast of Brazil (Figure 1), between January and December, 2008, in an area measuring approximately $600 \mathrm{~m}^{2}$. The Rio do Fogo River discharges near the G. birdiae bank (at a distance of approximately $500 \mathrm{~m}$ ) and, depending on the rainfall regime, accounts for the salinity and nutrient fluctuations recorded there. Two distinct seasons were identified at this site: (i) rainy, from March to August, and (ii) dry, in January and February and between September and December.

Samples of $G$. birdiae were obtained along a $10 \mathrm{~m}$ transect, from which twenty points were randomly selected. The collection procedure was repeated three times, totaling sixty sampling points each month. The individuals selected were measured directly in the field and samples of each specimen were collected and stored in plastic bags for laboratory analysis. Specimens were separated according to their reproductive stage (tetrasporophytes, cystocarpic plants, and male gametophytes). Tetrasporophytes and male gametophytes were identified with the help of histological cuts visualized under a microscope, while cystocarpic plants were identified with the naked eye by the presence of cystocarps on the thallus. Thalli without tetrasporangia, spermatangial conceptacles, and cystocarps were considered to be infertile.

\section{Environmental parameters}

Environmental parameters (water temperature, salinity, $\mathrm{pH}$, and water transparency) were recorded monthly by using a multiparameter probe (Horiba U-10) and a Secchi disk, simultaneously with seaweed collection. Water samples (300 $\mathrm{mL})$ were collected at the site, fixed $\left(2 \mathrm{M} \mathrm{H}_{2} \mathrm{SO}_{4}\right)$, filtered (Whatman $\mathrm{GF} / \mathrm{C}$ ) and frozen until analysis. Dissolved inorganic nitrogen $\left(\mathrm{DIN}=\mathrm{NH}_{4}^{+}+\mathrm{NO}_{3}^{-}\right.$

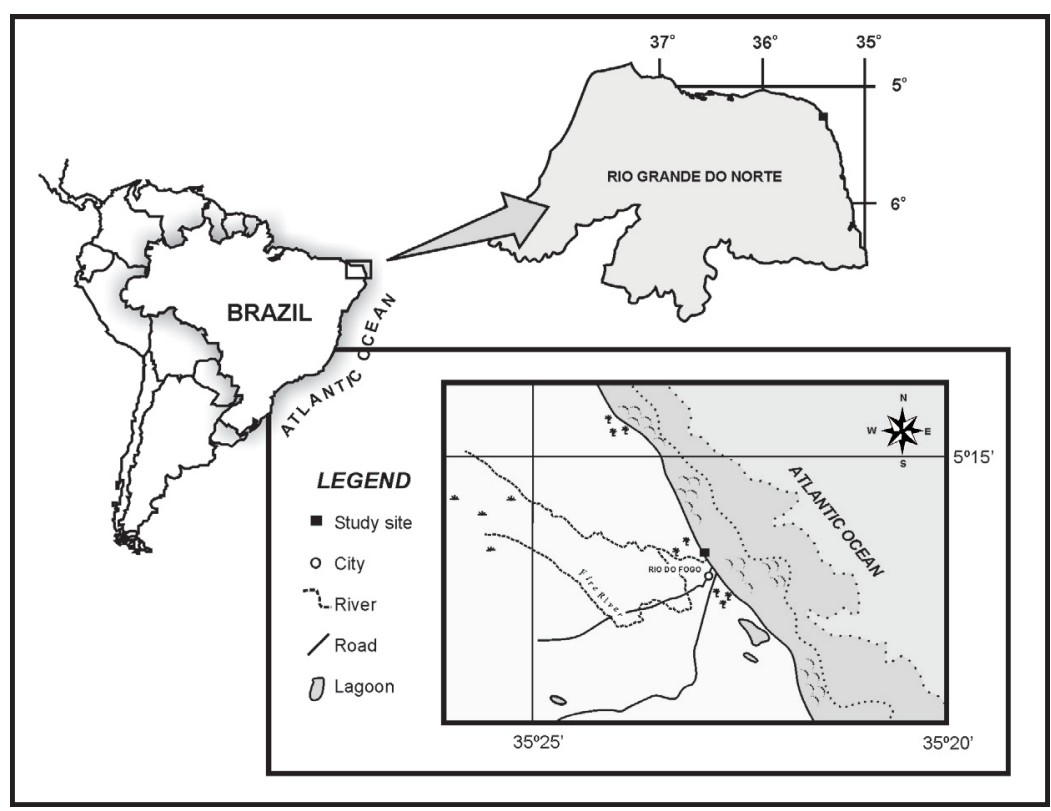

Figure 1. Map showing the study location: Rio do Fogo Beach, Rio Grande do Norte State, Brazil. 
$\left.+\mathrm{NO}_{2}^{-}\right)$and orthophosphate $\left(\mathrm{PO}_{4}^{3-}\right)$ were analyzed according to methods described by Strickland \& Parsons (1972). Rainfall and photosynthetically active radiation (PAR) were obtained from INPE (Brazilian National Space Research Institute). Rainfall values correspond to monthly accumulation (mm/month) and monthly PAR to daily means of values obtained every $30 \mathrm{~min}$.

\section{Statistical analyses}

Seasonal variations in the thallus length at different reproductive stages of Gracilaria birdiae and in the environmental parameters recorded during this study were analyzed using one-way ANOVA. When significant differences were detected, the posthoc Student-Newman-Keuls test was used. Student's t-test was applied to identify the differences between the rainy (March to August) and dry (September to February) seasons. Pearson's correlation was used to determine relationships existing between thallus length and the recorded environmental parameters. Sexual proportion analysis (cystocarpic plants $\mathrm{X}$ male plants) was conducted using the $\chi^{2}$ test. Data were analyzed for normality and homoscedasticity using the KolmogorovSmirnov and Levene tests, respectively. Data that did not meet the test premises were transformed $(\log 10, \ln$, and square root) or evaluated using the corresponding nonparametric tests.

\section{Results}

\section{Environmental parameters}

Table 1. Environmental parameters (range and mean \pm SD) recorded during the rainy and dry seasons of 2008.

\begin{tabular}{|c|c|c|c|c|c|c|}
\hline & \multicolumn{2}{|c|}{ Dry season } & \multicolumn{2}{|c|}{ Rainy season } & \multirow{2}{*}{ t-value } & \multirow{2}{*}{$p$} \\
\hline & Range & Mean \pm SD & Range & Mean \pm SD & & \\
\hline Rainfall (mm/month) & $0.2-67.8$ & $26.8 \pm 23.7$ & $286.3-542.0$ & $426.4 \pm 89.6$ & 19.46 & $<0.001$ \\
\hline PAR ( $\mu$ mol.photons. $\left.\mathrm{m}^{-2} \mathrm{~s}^{-1}\right)$ & 1158.9-1436.6 & $1284.2 \pm 98.27$ & $416.8-1077.2$ & $860.0 \pm 235.8$ & 13.01 & $<0.001$ \\
\hline Wide speed $\left(\mathrm{m} . \mathrm{s}^{-1}\right)$ & $4.74-6.00$ & $5.32 \pm 0.43$ & $3.14-5.01$ & $4.07 \pm 0.80$ & 3.37 & $<0.05$ \\
\hline Water temperature $\left({ }^{\circ} \mathrm{C}\right)$ & $27.0-29.0$ & $28.7 \pm 0.46$ & $26.0-29.0$ & $26.6 \pm 0.55$ & 3.08 & $<0.05$ \\
\hline Salinity (PSU) & $34.0-35.0$ & $34.8 \pm 0.4$ & $27.0-35.0$ & $33.3 \pm 3.1$ & 2.14 & $<0.05$ \\
\hline $\mathrm{pH}$ & $7.6-8.7$ & $8.2 \pm 0.0$ & $7.5-8.3$ & $7.8 \pm 0.3$ & 3.15 & $<0.05$ \\
\hline Water transparency $(\mathrm{cm})$ & $15.0-90.0$ & $47.0 \pm 29.4$ & $30.0-135.0$ & $79.6 \pm 38.9$ & 3.86 & $<0.001$ \\
\hline $\mathrm{NO}_{2}\left(\mu \mathrm{mol} \cdot \mathrm{L}^{-1}\right)$ & $0.04-0.17$ & $0.11 \pm 0.06$ & $0.05-0.19$ & $0.10 \pm 0.06$ & 0.63 & 0.535 \\
\hline $\mathrm{NO}_{3}\left(\mu \mathrm{mol} \cdot \mathrm{L}^{-1}\right)$ & $0.01-0.64$ & $0.23 \pm 0.30$ & $0.01-5.26$ & $1.17 \pm 2.05$ & 2.05 & $<0.05$ \\
\hline $\mathrm{NH}_{4}\left(\mu \mathrm{mol} \cdot \mathrm{L}^{-1}\right)$ & $0.25-2.34$ & $1.15 \pm 0.83$ & $0.60-6.48$ & $2.58 \pm 2.38$ & 2.54 & $<0.05$ \\
\hline DIN $\left(\mu \mathrm{mol} . \mathrm{L}^{-1}\right)$ & $0.50-3.04$ & $1.50 \pm 0.87$ & $0.79-9.66$ & $3.85 \pm 3.88$ & 2.67 & $<0.05$ \\
\hline $\mathrm{PO}_{4}\left(\mu \mathrm{mol} \cdot \mathrm{L}^{-1}\right)$ & $0.08-1.37$ & $0.64 \pm 0.55$ & $0.17-1.76$ & $0.71 \pm 0.73$ & 0.32 & 0.753 \\
\hline
\end{tabular}




\section{Phenology of G. birdiae}

Fertile specimens of $G$. birdiae were observed during the entire study period. Tetrasporophytes were found in larger amounts, with an annual mean of $80.1 \pm 5.6 \%$, followed by cystocarpic plants $(9.3 \pm 3.4 \%)$ and male gametophytes $(8.3 \pm 3.6 \%)$. Only $2.2 \pm 3.4 \%$ of the sampled individuals were infertile (Figure 2). The frequencies recorded for tetrasporophytes and cystocarpic plants were similar throughout the year $(p>0.05)$, while male gametophytes (max. $11.7 \pm 2.9 \%$ and $\min$. $1.7 \pm 2.9 \%$ ) and infertile plants (max. $10.0 \pm 0.9 \%$ and min. $0.0 \pm 0.0 \%)$ showed significant variations $(p<0.05)$. The proportion between female (cystocarpic plants) and male gametophytes was 1:1 in most of the months studied. In September, the occurrence of male plants was higher than cystocarpic plants $\left(1.8 \hat{\jmath}: 1 q ; \chi^{2}=8.16 ; p<0.05\right)$, while in February $\left(1 \delta: 2 q ; \chi^{2}=11.11 ; p<0.05\right)$ and October $\left(0.1 \hat{\delta}: 1\right.$; $\left.; \chi^{2}=66.94 ; p<0.05\right)$ it was the inverse, that is, cystocarpic plants were more numerous.

With respect to thallus length, a distinct seasonal variation $(p<0.05)$ was observed in all fertile stages, with the highest values recorded during the rainy season (tetrasporophytes- $41.4 \pm 1.7 \mathrm{~cm}$ (July); cystocarpic plants, $41.8 \pm 5.0 \mathrm{~cm}$ (July); male gametophytes, $37.9 \pm 8.7 \mathrm{~cm}$ (June)) (Figure 3 and Table 2). Mean thallus lengths for the rainy and dry seasons were $38 \pm 3.1 \mathrm{~cm}$ and $28.1 \pm 4.1$

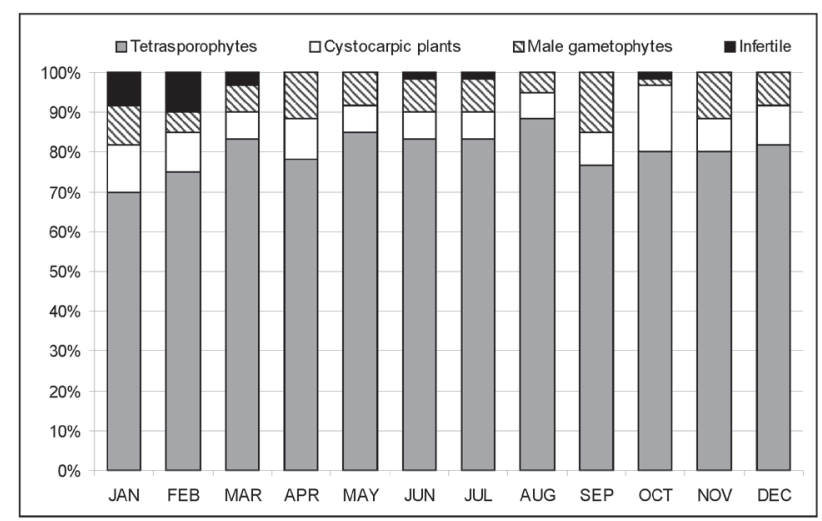

Figure 2. Frequencies of the different reproductive stages (tetrasporophytes, cystocarpic plants, and male gametophytes) and infertile plants of $G$. birdiae from Rio do Fogo Beach, Rio Grande do Norte State, Brazil, between January and December, 2008. $\mathrm{cm}$, (tetrasporophytes, $\mathrm{t}=8.01, p<0.05$ ), $35.4 \pm 4.2 \mathrm{~cm}$ and $28.3 \pm 5.5 \mathrm{~cm}$ (cystocarpic plants, $\mathrm{t}=3.59, \mathrm{p}<0.05$ ), and $34.6 \pm 2.9 \mathrm{~cm}$ and $22.1 \pm 4.6 \mathrm{~cm}$ (male gametophytes, $\mathrm{t}=4.52$, $p<0.05)$. Thallus lengths of the three fertile stages showed positive correlations with rainfall (tetrasporophytes, $\mathrm{r}=0.69, p<0.05$; cystocarpic plants, $\mathrm{r}=0.67, p<0.05$; male gametophytes, $\mathrm{r}=0.83, p<0.05)$ and negative correlations with PAR (tetrasporophytes, $\mathrm{r}=-0.80, p<0.05$; cystocarpic plants, $\mathrm{r}=-0.69, \mathrm{p}<0.05$; male gametophytes, $\mathrm{r}=-0.88$, $p<0.05)$. The lengths of infertile plants showed no significant differences between the two periods $(\mathrm{t}=0.85$, $p>0.05$ ), with means of $23.3 \pm 3.2$ and $21.6 \pm 4.3 \mathrm{~cm}$ for the rainy and dry seasons, respectively.

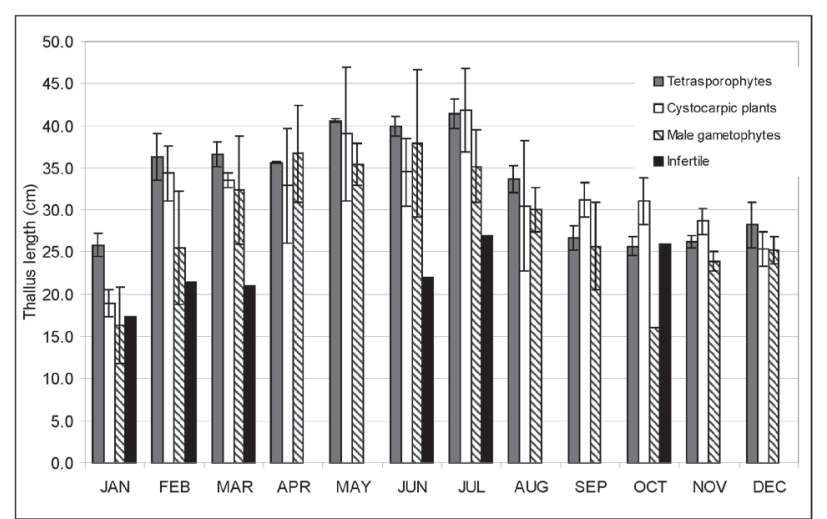

Figure 3. Mean thallus lengths for the different reproductive stages (tetrasporophytes, cystocarpic plants, and male gametophytes) and infertile plants of G. birdiae from Rio do Fogo Beach, Rio Grande do Norte State, Brazil, between January and December, 2008.

\section{Discussion}

Fertile plants of $G$. birdiae were found during the entire study period. The fertility of this population was evidenced by the small amount of infertile plants $(\sim 2 \%)$, which were recorded in only a few months of the year. Tetrasporophytes were found in larger amounts $(80.1 \pm 5.6 \%)$, followed by cystocarpic plants $(9.3 \pm 3.4 \%)$ and male gametophytes $(8.3 \pm 3.6 \%)$. Dominance of the tetrasporophytic phase was also recorded in natural populations of various species of this genus, including $G$. bursa-pastoris and G. coronopifolia in Hawaii (Hoyle, 1978), G. cornea in Mexico (Orduña-Rojas \& Robledo,

Table 2. Mean $( \pm \mathrm{SD})$, minimum and maximum thallus length values $(\mathrm{cm})$ of the different reproductive stages and infertile plants of G. birdiae from Rio do Fogo Beach, Rio Grande do Norte State, Brazil, during the rainy and dry seasons of 2008.

\begin{tabular}{|c|c|c|c|c|c|c|}
\hline & \multicolumn{2}{|c|}{ Dry season } & \multicolumn{2}{|c|}{ Rainy season } & \multirow{2}{*}{ t-value } & \multirow{2}{*}{$p$} \\
\hline & Range & Mean \pm SD & Range & Mean \pm SD & & \\
\hline Tetrasporophytes & $25.7-36.3$ & $28.2 \pm 4.1$ & $33.7-41.4$ & $38.0 \pm 3.1$ & -8.05 & 0.000 \\
\hline Cistocarpic plants & $18.9-34.3$ & $28.3 \pm 5.5$ & $30.5-41.8$ & $35.4 \pm 4.2$ & -3.60 & 0.001 \\
\hline Male gametophyte & $16.0-25.7$ & $22.1 \pm 4.6$ & $30.0-37.9$ & $34.6 \pm 2.9$ & -4.52 & 0.000 \\
\hline Infertile plants & $17.4-26.0$ & $21.6 \pm 4.3$ & $21.0-27.0$ & $23.3 \pm 3.2$ & -0.86 & 0.413 \\
\hline
\end{tabular}


2002), G. damaecornis in Venezuela (Brito \& Silva, 2004), G. gracilis in Italy (Polifrone et al., 2006), and G. gracilis in Argentina (Martín et al., 2010). Studies suggest that tetrasporophytic dominance in nature may be related to the higher carpospore viability and survival rates as compared to the haploid stages (Destombe et al., 1989). According to Yokoya \& Oliveira (1993), this dominance is due to the fact that diploid cells are supposedly more tolerant to environmental variations than haploid cells, which would explain the predominance of the tetrasporophytic phase in natural populations.

Over the course of the study, the sexual proportion of $G$. birdiae was 1:1 in most of the months studied, except February $(\widehat{\jmath} 1: q 2 ; \chi 2=11.11 ; p<0.05)$, September $\left({ }^{\lambda} 1.8:+1 ; ; \chi^{2}=8.16 ; p<0.05\right)$ and October $\left(\delta^{\top} 0.1: \circ 1 ; \chi^{2}=66.94 ; p<0.05\right)$. The significant increase in cystocarpic plants in October may be related to the greater proportion of male plants observed in the previous month $(p<0.06)$. Earlier studies showed that inversion between the proportions of male and female plants may occur during peaks of sexual reproduction. These studies also underscore the fact that large amounts of cystocarpic plants commonly appear after a high frequency of male plants is recorded (Kain (Jones) \& Destombe, 1995; Espinoza-Avalos, 2005). Infertile plants accounted for an insignificant portion of the population, compared to the other reproductive stages (tetrasporophytes and fertile gametophytes). However, their appearance was synchronized semi-monthly, supposedly after spore release, indicating the presence of juveniles from other reproductive stages.

In relation to thallus size, a clear seasonal variation was observed, with the highest values recorded in the rainy season and the lowest in the dry season. This type of seasonal model was also observed in other species of Gracilaria in tropical regions (Silva et al., 1987; Luhan, 1996; Orduña-Rojas \& Robledo, 2002). During part of the rainy period (March-August), environmental conditions were characterized by waters rich in nutrients transported to the sea by the heavy rainfall. This supply of nutrients favored the luxuriant growth of G. birdiae until the month of August. The decreased thallus length from the month of August onward coincided with the increase in wind speed, waves, currents, and sediment displacement towards the seaweed banks. The combined effect of these factors between August and November contributed to the partial interment of the G. birdiae population and, in turn, to thallus fragmentation.

The effect of sediment load on seaweeds probably hindered thallus regeneration and contributed to the decreased recruitment, growth, and survival rate of the specimens. Eriksson \& Johansson (2003, 2005) suggest that high sediment load is a negative factor for recruitment, growth, and fixation of spores. Thus, the marked presence of small infertile individuals in
January, after hydrodynamic disturbances, indicates the restoration of the G. birdiae population and demonstrates the important effect of environmental conditions on the reproductive phenology of this population.

The results obtained in the present study provide relevant information about the reproductive aspects of a natural population of G. birdiae, located at Rio do Fogo Beach, in Northeastern Brazil. This knowledge is important for developing sustainable management and commercial exploitation programs for this natural resource.

\section{Acknowledgements}

FAPESP.

This research was supported by the CNPq and

\section{References}

Araújo P 2005. Ecologia populacional de Gracilaria birdiae (Gracilariales, Rhodophyta) na Área de Proteção Ambiental da Barra do Rio Mamanguape, Paraíba, Brasil. Recife, 95 p. Dissertação de Mestrado, Programa de Pós-graduação em Oceanografia, Universidade Federal de Pernambuco.

Armisen R 1995. World-wide use and importance of Gracilaria. $J$ Appl Phycol 7: 231-243.

Bezerra AF, Marinho-Soriano E 2010. Cultivation of the red seaweed Gracilaria birdiae (Gracilariales, Rhodophyta) in tropical waters of northeast Brazil. Biomass Bioenerg 34: 1813-1817.

Brito LL, Silva ST 2004. Fases reproductivas de Gracilaria damaecornis J. Agardh (Gracilariaceae: Rhodophyta). Bol Inst Oceanogr Venezuela Univ Oriente 43: 33-36.

Critchley AT 1993. Gracilaria (Rhodophyta, Gracilariales): An economically important agarophyte. In Ohno M \& Critchley AT (eds.) Seaweed Cultivation and Marine Rancing, Yokosuka: JICA, p. 89-112.

Costa VL, Plastino ME 2001. Histórico de vida de espécimens selvagens e variantes cromáticas de Gracilaria sp. (Gracilariales, Rhodophyta). Rev Bras Bot 24: 491-500.

Costa VL, Plastino ME 2011. Color inheritance and pigment characterization of red (wild-type), greenish-brown, and green strains of Gracilaria birdiae (Gracilariales, Rhodophyta). J Appl Phycol DOI 10.1007/s10811-0109642-3.

Destombe C, Valero M, Vernet P, Couvet D 1989. What controls haploid-diploid ratio in the red alga, Gracilaria verrucosa? J Evol Biol 2:317-338

Eriksson BK, Johansson G 2003. Sedimentation reduces recruitment success of Fucus vesiculosus in the Baltic Sea. Eur J Phycol 38: 217-222.

Eriksson BK, Johansson G 2005. Effects of sedimentation on macroalgae: species-specific responses are related to reproductive traits. Oecologia 143: 438-448.

Espinoza-Avalos J 2005. Fenología de macroalgas marinas. Hidrobiologica 15: 109-122.

Hoyle MD 1978. Reproductive phenology and growth rates in two species of Gracilaria from Hawaii. J Exp Mar Biol 
Ecol 35: 273-283.

Kain (Jones) JM, Destombe C 1995. A review of the life history, reproduction and phenology of Gracilaria. J Appl Phycol 7: 269-281.

Luhan MRJ 1996. Biomass and reproductive states of Gracilaria heteroclada Zhang et Xia collected from Jaro, central Philippines. Bot Mar 39: 207-211.

Marinho-Soriano E, Laugier T, De Casabianca M L 1998. Reproductive strategy of two Gracilaria species, $G$. bursa-pastoris and G. gracilis, in a Mediterranean Lagoon (Thau, France). Bot Mar 41: 559-564.

Marinho-Soriano E, Moreira WSC, Carneiro MAA 2006. Some aspects of the growth of Gracilaria birdiae (Gracilariales, Rhodophyta) in an estuary in northeast Brazil. Aquacult Int 14: 327-336.

Marinho-Soriano E, Nunes SO, Carneiro MAA, Pereira DC 2009. Nutrients' removal from aquaculture wastewater using the macroalgae Gracilaria birdiae. Biomass Bioenerg 33: 327-331.

Martín LA, Zaixso ALB, Leonardi PI 2010. Biomass variation and reproductive phenology of Gracilaria gracilis in a Patagonian natural bed (Chubut, Argentina). J Appl Phycol DOI: 10.1007/s10811-010-9555-1.

McHugh DJ 2002. Prospects for seaweed production in developing countries. Rome: FAO Fisheries Circular. No. 968,28 p.

Oliveira VP 2007. Influência da profundidade e dos parâmetros ambientais sobre o desenvolvimento de Gracilaria birdiae (Rhodophyta, Gracilariales) em viveiros de camarão. Dissertação de Mestrado. Natal, 54 p. Programa de Pós-graduação em Bioecologia Aquática, Universidade Federal do Rio Grande do Norte.

Oliveira EC, Plastino EM 1994. Gracilariaceae. In Akatsuka I (ed.) Biology of Economic Algae. The Hague: SPB Academic Publishing, p. 185-226.

Orduña-Rojas J, Robledo D 2002. Studies on the tropical agarophyte Gracilaria cornea J. Agardh (Rhodophyta, Gracilariales) from Yucatán, México. II. Biomass assessment and reproductive phenology. Bot Mar 45: 459-464

Pinheiro-Joventino F, Bezerra CLF 1980. Estudo de fenologia e regeneração de Gracilaria domingensis Sonder (Rhodophyta-Gracilariaceae), no estado do Ceará. Arq Cien Mar 20: 33-41.

Plastino, EM 1985. As espécies de Gracilaria (Rhodophyta, Gigartinales) da Praia Dura, Ubatuba, SP-aspectos biológicos e fenologia. São Paulo, 124 p. Dissertação de Mestrado. Programa de Pós-graduação em Ciências Biológicas (Botânica). Universidade de São Paulo.

Plastino EM 2004. Diversidade intraespecifica em algas gracilarióides. São Paulo, 46 p. Livre-docência, Universidade de São Paulo.
Plastino EM, Oliveira EC 2002. Gracilaria birdiae (Gracilariales, Rhodophyta), a new species from the Tropical South American Atlantic with a terete frond and deep spermatangial conceptacles. Phycologia 41: 389-396.

Plastino EM, Ursi S, Fujii MT 2004. Color inheritance, pigment characterization, and growth of a rare light green strain of Gracilaria birdiae (Gracilariales, Rhodophyta). Phycol Res 52: 45-52.

Polifrone M, Masi FD, Gargiulo GM 2006. Alternative pathways in the life history of Gracilaria gracilis (Gracilariales, Rhodophyta) from north-eastern Sicily (Italy). Aquaculture 261: 1003-1013.

Richerd S, Destombe C, Cuguen J, Valero M 1993. Variation of reproductive success in a haplo-diploid red alga, Gracilaria verrucosa: effects of parental identities and crossing distance. Am J Bot 80: 578-584.

Silva RL, Pereira SMB, Oliveira EC, Eston, VR 1987. Structure of a bed of Gracilaria spp (Rhodophyta) in northeastern Brazil. Bot Mar 30: 517-523.

Strickland JDH, Parsons TR 1972. A practical handbook of seawater analysis. Ottawa: Fisheries Research Board of Canada.

Ursi S, Plastino E M 2001. Crescimento in vitro de linhagens de coloração vermelha e verde clara de Gracilaria sp. (Gracilariales, Rhodophyta) em dois meios de cultura: análise de diferentes estádios reprodutivos. Rev Bras Bot 24: 587-594

Ursi S, Pedersen M, Plastino E, Snoeijs P 2003. Intraspecific variation of photosynthesis, respiration and photoprotective carotenoids in Gracilaria birdiae (Gracilariales: Rhodophyta). Mar Biol 142: 997-1007.

Ursi S, Guimarães M, Plastino EM 2008. Deleterious effect of TRIS buffer on growth rates and pigment content of Gracilaria birdiae Plastino and E.C. Oliveira (Gracilariales, Rhodophyta). Acta Bot Bras 22: 891-896.

Yokoya N, Oliveira E 1993. Effects of temperature and salinity on spore germination and sporeling development in South American agarophytes (Rhodophyta). Jpn $J$ Phycol 41: 283-293.

Zar JH 1999. Biostatistical Analysis, 4 ed. New Jersey: Prentice Hall.

\section{*Correspondence}

Estela M. Plastino

Departamento de Botânica, Instituto de Biociências, Universidade de São Paulo Rua do Matão 277, Cidade Universitária, 05508090 São Paulo-SP, Brazil

emplasti@usp.br

Tel. +55 1130917544

Fax:+55 1130917547 